\title{
Small-scale variation of snow in a regional permafrost model
}

\author{
Kjersti Gisnås $^{1}$, Sebastian Westermann ${ }^{1}$, Thomas Vikhamar Schuler ${ }^{1}$, Kjetil Melvold $^{2}$, and Bernd Etzelmüller ${ }^{1}$ \\ ${ }^{1}$ Department of Geosciences, University of Oslo, Oslo, Norway \\ ${ }^{2}$ Norwegian Water Resources and Energy Directorate, Oslo, Norway
}

Correspondence to: Kjersti Gisnås (kjersti.gisnas@geo.uio.no)

Received: 10 November 2015 - Published in The Cryosphere Discuss.: 8 December 2015

Revised: 21 April 2016 - Accepted: 23 May 2016 - Published: 3 June 2016

\begin{abstract}
The strong winds prevalent in high altitude and arctic environments heavily redistribute the snow cover, causing a small-scale pattern of highly variable snow depths. This has profound implications for the ground thermal regime, resulting in highly variable near-surface ground temperatures on the metre scale. Due to asymmetric snow distributions combined with the nonlinear insulating effect of snow, the spatial average ground temperature in a $1 \mathrm{~km}^{2}$ area cannot be determined based on the average snow cover for that area. Land surface or permafrost models employing a coarsely classified average snow depth will therefore not yield a realistic representation of ground temperatures. In this study we employ statistically derived snow distributions within $1 \mathrm{~km}^{2}$ grid cells as input to a regional permafrost model in order to represent sub-grid variability of ground temperatures. This improves the representation of both the average and the total range of ground temperatures. The model reproduces observed sub-grid ground temperature variations of up to $6^{\circ} \mathrm{C}$, and $98 \%$ of borehole observations match the modelled temperature range. The mean modelled temperature of the grid cell reproduces the observations with an accuracy of $1.5^{\circ} \mathrm{C}$ or better. The observed sub-grid variations in ground surface temperatures from two field sites are very well reproduced, with estimated fractions of sub-zero mean annual ground surface temperatures within $\pm 10 \%$. We also find that snow distributions within areas of $1 \mathrm{~km}^{2}$ in Norwegian mountain environments are closer to a gamma than to a lognormal theoretical distribution. The modelled permafrost distribution seems to be more sensitive to the choice of distribution function than to the fine-tuning of the coefficient of variation. When incorporating the small-scale variation of snow, the modelled total permafrost area of mainland
\end{abstract}

Norway is nearly twice as large compared to the area obtained with grid-cell average snow depths without a sub-grid approach.

\section{Introduction}

High altitude and arctic environments are exposed to strong winds and drifting snow can create a small-scale pattern of highly variable snow depths. Seasonal snow cover is a crucial factor for the ground thermal regime in these areas (e.g. Goodrich, 1982; Zhang et al., 2001). This smallscale pattern of varying snow depths results in highly variable ground surface temperatures on the metre scale of up to $6^{\circ} \mathrm{C}$ in areas of less than $1 \mathrm{~km}^{2}$ (e.g. Gubler et al., 2011; Gisnås et al., 2014). Grid-based numerical land surface and permafrost models operate on scales too coarse to resolve the variability of snow depths and are not capable of representing such small-scale variability. For the Norwegian mainland, permafrost models have been implemented with a spatial grid resolution of $1 \mathrm{~km}^{2}$ (Gisnås et al., 2013; Westermann et al., 2013) and therefore only represent the larger-scale patterns of ground temperatures. As a consequence, they usually represent the lower limit of permafrost as a sharp boundary, where the average ground temperature of a grid-cell crosses the freezing temperature $\left(0^{\circ} \mathrm{C}\right)$. In reality, the lower permafrost boundary is a fuzzy transition. Local parameters, such as snow cover, solar radiation, vegetation, soil moisture and soil type, cause a pronounced sub-grid variation of ground temperature. Different approaches have been developed to address this mismatch of scales, such as the TopoSub (Fiddes and Gruber, 2012), accounting for the variabil- 
ity of a range of surface parameters using $k$-means clustering. At high latitudes and altitudes, one of the principal controls on the variability of ground temperature is the effect of subgrid variation in snow cover (e.g. Langer et al., 2013). The observed variability in ground surface temperatures within $1 \mathrm{~km} \times 1 \mathrm{~km}$ areas is to a large degree reproduced by only accounting for the variation in snow depths (Gisnås et al., 2014). Therefore, procedures capable of resolving the smallscale variability of snow depths could considerably improve the representation of the ground thermal regime.

The spatial variation of snow is a result of several mechanisms operating on different scales in different environments (Liston, 2004). In tundra and alpine areas, wind-affected deposition is the dominant control on the snow distribution at distances below $1 \mathrm{~km}$ (Clark et al., 2011). Physically based snow distribution models are useful over smaller areas but are not applicable on a regional scale. The coefficient of variation (CV), defined as the ratio between the standard deviation and the mean, is a measure of the extent of spread in a distribution. The $\mathrm{CV}$ of snow depths $\left(\mathrm{CV}_{\mathrm{sd}}\right)$ typically range from low spread at 0.2 to high spread at 0.8 , which suits snow distributions in a range of environments (e.g. Liston, 2004; Winstral and Marks, 2014). Liston (2004) assigned individual values of $\mathrm{CV}_{\text {sd }}$ to different land use classes in order to address sub-grid variability of snow in land surface schemes. According to this scheme, non-forested areas in Norway, as well as most of the permafrost areas in northern Europe ("high-latitude alpine areas"), would have been allocated a $\mathrm{CV}_{\mathrm{sd}}$ of 0.7. A review of observed $\mathrm{CV}_{\mathrm{sd}}$ from a large number of snow surveys in the northern hemisphere shows a large spread of $\mathrm{CV}_{\text {sd }}$ values, in particular within this land use class, ranging from 0.1 to 0.9 (Clark et al., 2011). This illustrates the need for improved representation of snow distribution within this land use class.

An accurate representation of the small-scale snow variation influences the timing and magnitude of runoff in hydrological models, and a detailed picture of the sub-grid variability is of great value for the hydropower industry and flood forecasting. Adequate representations of the snow covered fraction in land surface schemes improve simulated nearsurface air temperatures, ground temperatures and evaporation due to the considerable influence of snow cover on the duration of melt season and the surface albedo.

In this study we derive functional dependencies between distributions of snow depth within $1 \mathrm{~km} \times 1 \mathrm{~km}$ grid cells and $\mathrm{CV}_{\text {sd }}$, based on an extensive in situ dataset from Norwegian alpine areas. In a second step, we employ the resulting snow distributions as input to the permafrost model CryoGRID1, a spatially distributed, equilibrium permafrost model (Gisnås et al., 2013). Using a sub-grid representation of ground temperatures, permafrost probabilities are derived, hence enabling a more realistic, fuzzy permafrost boundary instead of a binary, sharp transition. With this approach, we aim to improve permafrost distribution modelling in inhomogeneous terrains.

\section{Setting}

The model is implemented for the Norwegian mainland, extending from 58 to $71^{\circ} \mathrm{N}$. Both the topography and climate in Norway is dominated by the Scandes, a mountain range stretching south-north through Norway, separating the coastal western part with steep mountains and deep fjords from the eastern part where the mountains gradually decrease in height. The maritime climate of the west coast is dominated by low-pressure systems from the Atlantic Ocean resulting in heavy precipitation, while the eastern parts of the Scandes have a more continental and drier climate. Mountain permafrost is present all the way to the southern parts of the Scandes, with a gradient in the lower limit of permafrost from $\sim 1400$ to $1700 \mathrm{~m}$ from east to west in central southern Norway and from $\sim 700$ to $1200 \mathrm{~m}$ from east to west in northern Norway (Gisnås et al., 2013). While permafrost is also found in mires at lower elevations both in southern and northern Norway, most of the permafrost is located in exposed terrain above the treeline where strong winds result in heavy redistribution of snow.

The in situ records of snow depth data used to establish the snow distribution scheme were collected at the Hardangervidda mountain plateau in the southern part of the Scandes (Fig. 1). It is the largest mountain plateau in northern Europe, located at elevations from 1000 to above $1700 \mathrm{~m}$ a.s.l., with occurrences of permafrost in the highest mountain peaks. The terrain is open and slightly undulating in the east, while in the west it is more complex with steep mountains divided by valleys and fjords. The mountain range represents a significant orographic barrier for the prevailing westerly winds from the Atlantic Ocean, giving rise to large variations in precipitation and strong winds, two agents promoting a considerably wind-affected snow distribution. Mean annual precipitation varies from 500 to more than $3000 \mathrm{~mm}$ over distances of a few tens of kilometres, and maximum snow depths can vary from 0 to more than $10 \mathrm{~m}$ over short distances (Melvold and Skaugen, 2013).

\section{Model description}

\subsection{A statistical model for snow depth variation}

The Winstral terrain-based approach (Winstral et al., 2002) is applied over the entire Norwegian mainland using the $10 \mathrm{~m}$ national digital terrain model from the Norwegian Mapping Authority (available at Statkart.no), with wind data from the NORA10 dataset (Sect. 4.1) used to indicate the distribution of prevailing wind directions during the accumulation season.

The terrain-based exposure parameter $(S x)$, described in detail in Winstral et al. (2002), quantifies the extent of shelter or exposure of the considered grid-cell. $S x$ is determined by the slope between the grid-cell and the cells of greatest 


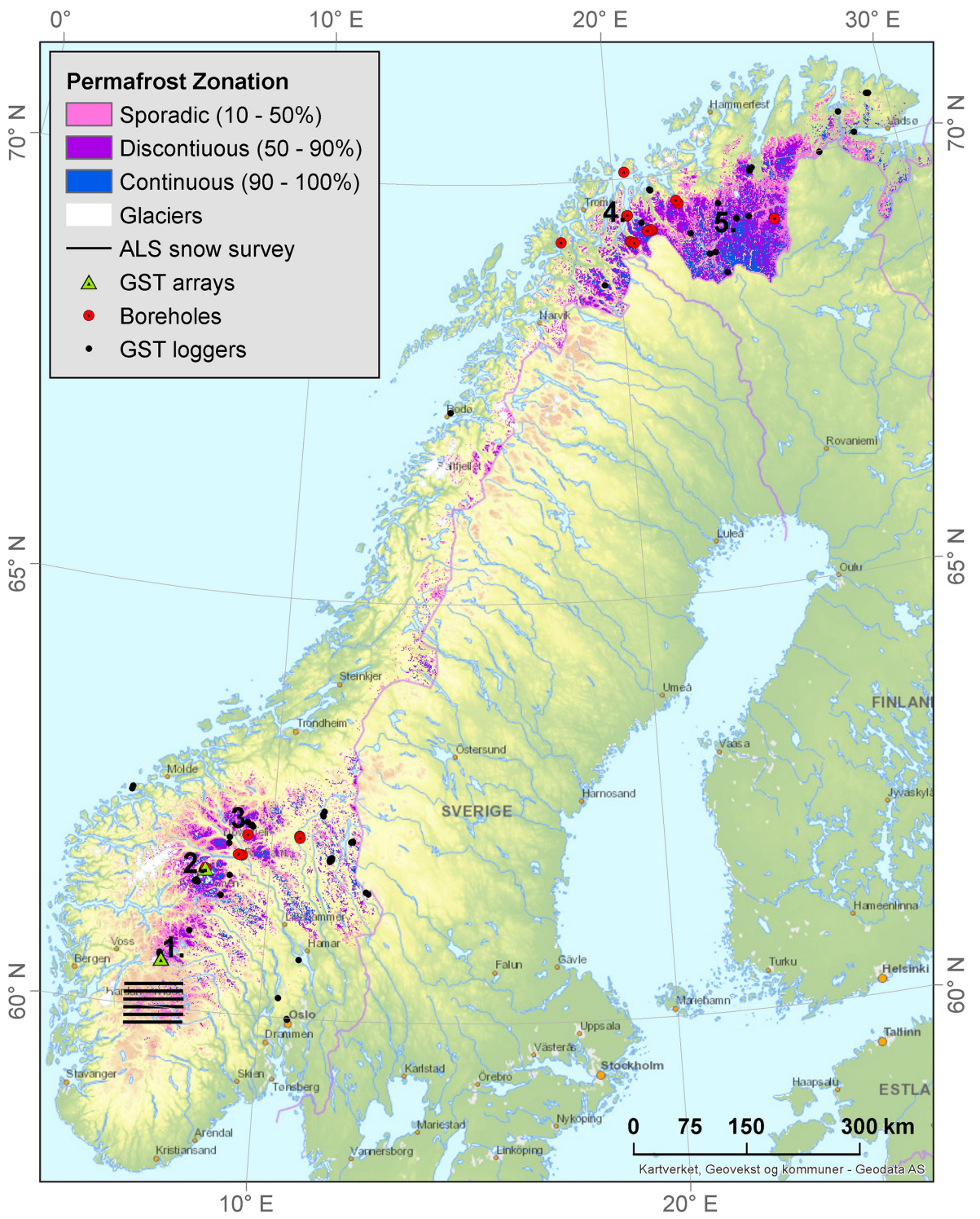

Figure 1. Modelled distribution of permafrost in Norway. Sites mentioned in the text: (1) Finse, south of Hallingskarvet; (2) Juvvasshøe in Jotunheimen; (3) Dovrefjell; (4) the Lyngen Alps; and (5) Finnmark.

upward slope in the upwind terrain. The upwind terrain is defined as a sector towards the prevailing wind direction $d$ constrained by the maximum search distance $\left(d_{\max }=100 \mathrm{~m}\right)$ and a chosen width $(A)$ of $30^{\circ}$ with the two azimuths extending $15^{\circ}$ to each side of $d$ (see Fig. 2). The cell of the maximum upward slope is identified for each search vector, separated by $5^{\circ}$ increments. This gives in total seven search vectors for each of the eight $30^{\circ}$ wide sectors. $S x$ for the given grid-cell is finally calculated as the average of the maximum upward slope gradient of all seven search vectors:

$S x_{d, A, d_{\max }}\left(x_{i} y_{i}\right)=\max \left[\tan \left(\frac{Z\left(x_{v}, y_{v}\right)-Z\left(x_{i}, y_{i}\right)}{\left[\left(x_{v}-x_{i}\right)^{2}+\left(y_{v}-y_{i}\right)^{2}\right]^{0.5}}\right)\right]$, where $d$ is the prevailing wind direction, $\left(x_{i}, y_{i}\right)$ are the coordinates of the considered grid-cell, and $\left(x_{v}, y_{v}\right)$ are the sets of all cell coordinates located along the search vector defined by $\left(x_{i}, y_{i}\right), A$ and $d_{\max }$. This gives the degree of exposure or shelter in the range -1 to 1 , where negative values correspond to exposure.

To estimate a realistic degree of exposure based on the observed wind pattern at a local site, $S x$ was computed for each of the eight prevailing wind directions $d=[0,45,90,135$, $\left.180,225,270,315^{\circ}\right]$ and weighted based on the wind fraction $\left(\mathrm{wf}_{d}\right) . \mathrm{wf}_{d}$ accounts for the amount of different exposures in the terrain at various wind directions and represents the fraction of hourly wind direction observations over the accumulation season for the eight wind directions. The se- 


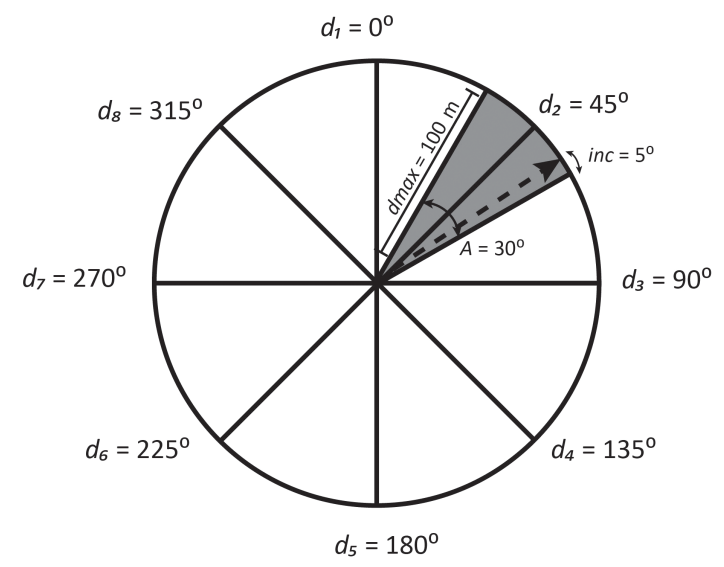

Figure 2. The area accounted for in each of the eight runs of the Winstral terrain-based parameter, each of them with a prevailing wind direction $d_{n}$. The area accounted for when calculating the exposure of a grid cell is constrained by the search window $(A)$ and the search distance $d_{\max }$ being $100 \mathrm{~m}$ upwind.

lected period of wind directions influencing the redistribution of snow is January to March. Wind speeds below a threshold of $7 \mathrm{~ms}^{-1}$ are excluded, as this threshold is considered a lower limit required for wind drifting of dry snow ( $\mathrm{Li}$ and Pomeroy, 1997; Lehning and Fierz, 2008). We assume that the snow distribution at snow maximum is highly controlled by the terrain and the general wind exposure over the winter season, and we do not account for the variation in snow properties over the season that controls how much snow is available for transport at a given time.

The calculated $S x$ parameter values are used as predictors in different regression analyses to describe the $\mathrm{CV}_{\mathrm{sd}}$ within $1 \times 1 \mathrm{~km}$ derived from an airborne laser scanning (ALS) of snow depths (see Sect. 4.1). The coefficient of variation of exposure degrees $\left(\mathrm{CV}_{\mathrm{Sx}}\right)$ within each $1 \mathrm{~km} \times 1 \mathrm{~km}$ grid cell is computed by aggregating the $S x$ map from $10 \mathrm{~m}$ to $1 \mathrm{~km}$ resolution according to

$\mathrm{CV}_{S x}=\operatorname{std}\left(e^{S x}\right) / \operatorname{mean}\left(e^{S x}\right)$.

$S x$ values below the 2.5th and above 97.5th percentiles of the $S x$ distributions are excluded, giving $S x \approx[-0.2,0.2]$. Three regression analyses were performed to reduce the root mean square error (RMSE) between $\mathrm{CV}_{\mathrm{Sx}}$ and observed $\mathrm{CV}_{\mathrm{sd}}$, where additional predictors such as elevation above treeline $(z)$ and maximum snow depth $(\mu)$ have been included (Table 1). Ideally, wind speed should be included as predictor. However, the NORA10 dataset (Sect. 4.1) does not sufficiently reproduce the local variations in wind speeds over land, especially not at higher elevations and for terrain with increased roughness. Elevation above treeline is chosen as predictor to account for the increased wind exposure with elevation. There is a strong gradient in treeline and general elevation of mountain peaks from high mountains in the south to lower topography in the north of Norway. Therefore, applying only elevation, not adjusted for the local treeline, as predictor would result in an underestimation of redistribution in the north.

\subsection{CryoGRID 1 with an integrated sub-grid scheme for snow variation}

The equilibrium permafrost model CryoGRID 1 (Gisnås et al., 2013; Westermann et al., 2015) provides an estimate for the MAGST (mean annual ground surface temperature) and MAGT (mean annual ground temperature at the top of the permafrost or at the bottom of the seasonal freezing layer) from freezing $\left(\mathrm{FDD}_{\mathrm{a}}\right)$ and thawing $\left(\mathrm{TDD}_{\mathrm{a}}\right)$ degree days in the air according to

MAGST $=\frac{\mathrm{TDD}_{\mathrm{a}} \times n T-\mathrm{FDD}_{\mathrm{a}} \times n F}{P}$,

and

MAGT $=\left\{\begin{array}{ll}\frac{\left(\mathrm{TDD}_{\mathrm{a}} \cdot n T \cdot r_{k}-\mathrm{FDD}_{\mathrm{a}} \cdot n F\right)}{P} & \text { for } K_{t} \mathrm{TDD}_{\mathrm{s}} \leq K_{f} \mathrm{FDD}_{\mathrm{s}} \\ \frac{\left(\mathrm{TDD}_{\mathrm{a}} \cdot n T-\frac{1}{r_{k}} \cdot \mathrm{FDD}_{\mathrm{a}} \cdot n F\right)}{P} & \text { for } K_{t} \mathrm{TDD}_{\mathrm{s}} \geq K_{f} \mathrm{FDD}_{\mathrm{s}}\end{array}\right.$,

where $P$ is the period that $\mathrm{FDD}_{\mathrm{a}}$ and $\mathrm{TDD}_{\mathrm{a}}$ are integrated over, $r_{k}$ is the ratio of thermal conductivities of the ground in thawed and frozen states (assuming that heat transfer in the ground is entirely governed by heat conduction), while $n T$ and $n F$ are semi-empirical transfer functions which aim to capture a variety of key processes in one single variable (see Gisnås et al. (2013) and Westermann et al. (2015) for details).

The winter $n F$ factor relates the freezing degree days at the surface to the air and thus accounts for the effect of the winter snow cover, and likewise the $n T$ factor relates the thawing degree days at the surface to the air and accounts for the surface vegetation cover:

$\mathrm{FDD}_{\mathrm{s}}=n F \mathrm{FDD}_{\mathrm{a}}$ and $\mathrm{TDD}_{\mathrm{s}}=n T \cdot \mathrm{TDD}_{\mathrm{a}}$.

Variation in observed $n$ factors for forests and shrubs are relatively small, with $n T$ factors typically in the range 0.85 to 1.1 , and $n F$ factors in the range 0.3 to 0.5 (Gisnås et al., 2013). Forest, shrubs and mires are assigned $n T$ factors 0.9/1.0/0.85 and $\mathrm{nF}$ factors 0.4/0.3/0.6 respectively (Gisnås et al., 2013).

Observed variations in $n T$ and $n F$ within the open nonvegetated areas are comparably large, with values typically in the range $0.4-1.2$ for $n T$ and $0.1-1.0$ for $n F$. The variability is related to the high impact and high spatial variability of snow depths (Gisnås et al., 2014). While $n F$ accounts for the insulation from snow due to low thermal conductivity, $n T$ indirectly compensates for the shorter season of thawing degree days at the ground surface in areas with a thick snow cover. Relationships between $n$ factors for open areas and maximum snow depths are established based on air and ground temperature observations together with snow depth 

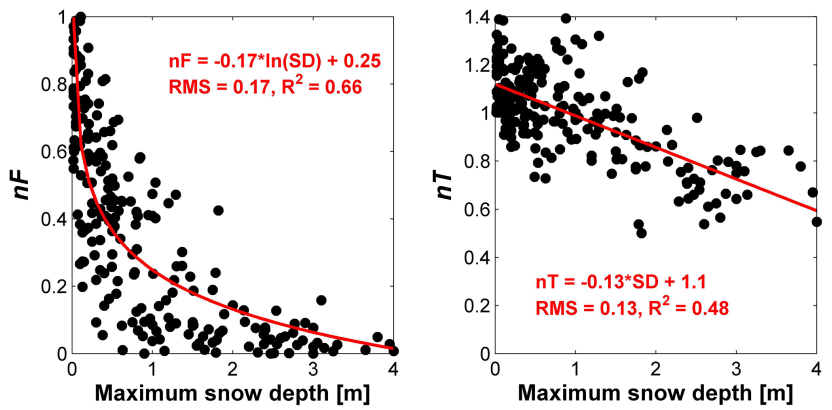

Figure 3. $n F$ and $n T$ related to maximum snow depth observed at more than 90 sites located above $1000 \mathrm{~m}$ a.s.l. in southern Norway.

observations at the end of accumulation season at the 13 stations in southern Norway, presented in Hipp (2012) and at arrays of nearly 80 loggers at Finse and Juvvasshøe (Gisnås et al., 2014) (Fig. 3):

$n F=-0.17 \cdot \ln (\mu)+0.25$,

$n T=-0.13 \cdot \mu+1.1$.

The relationships between $n$ factors and snow cover in open areas are shown to be consistent within the two sites in southern Norway (Gisnås et al., 2014). Due to lack of field observations including all required variables at one site in northern Norway, the relation is not tested for this area. However, it fits very well with a detailed study with 107 loggers recording the variation in ground surface temperature at a lowland site in Svalbard (Gisnås et al., 2014). Other factors, such as solar radiation and soil moisture, have minor effects on the smallscale variation in ground surface temperatures in these areas. Gisnås et al. (2014) demonstrated that most of the sub-grid variation in ground temperatures within $1 \mathrm{~km} \times 1 \mathrm{~km}$ areas in Norway and Svalbard was reproduced by including only the sub-grid variation of snow depths. In other areas, other parameters than snow depth might have a larger effect on the ground surface temperatures and should be accounted for in the derivation of $n$ factors.

We assume that the distribution of maximum snow depths within a grid cell with a given $\mathrm{CV}_{\mathrm{sd}}$ and average maximum snow depth $(\mu)$ follows a gamma distribution with a probability density function (PDF) given by

$f(x ; \alpha, \beta)=\frac{1}{\beta^{\alpha} \Gamma(\alpha)} x^{\alpha-1} e^{-\frac{x}{\beta}}$,

with a shape parameter $\alpha=\mathrm{CV}_{\text {sd }}^{-2}$ and a rate parameter $\beta=\mu \cdot \mathrm{CV}_{\text {sd }}^{2}$ (e.g. Skaugen et al., 2004; Kolberg and Gottschalk, 2006). The average maximum snow depth corresponds to the coarse-scale snow observation, and the original coarse-scale snow depth is therefore conserved in the sub-grid snow distribution. Corresponding $n$ factors are computed for all snow depths ( $x$ ) based on Eqs. (6) and (7) and related to the PDF (Eq. 8). The model is run for each $n F$ from 0

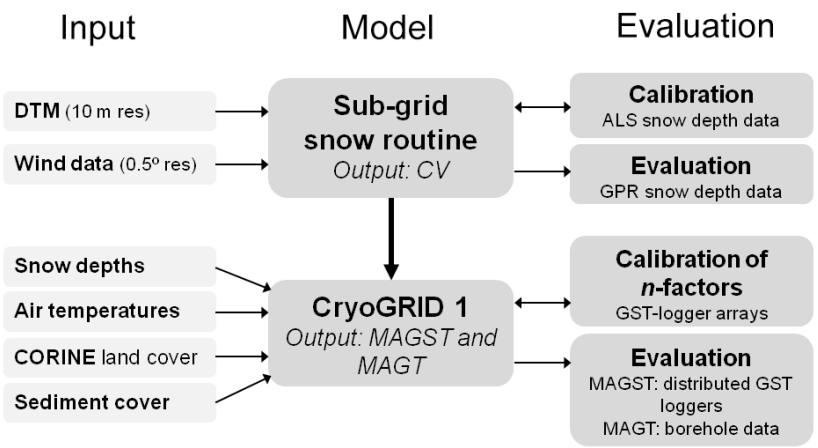

Figure 4. Schematic of the model chain, including input data, calibration and evaluation procedures.

to 1 with 0.01 spacing, giving 100 model realisations. Each realisation corresponds to a unique snow depth, represented with a set of $n F$ and $n T$ factors. Based on the 100 realisations, distributions of MAGST and MAGT are calculated for each grid cell, where the potential permafrost fraction is derived as the percentage of sub-zero MAGT. A schematic overview of the model chain and the evaluation is shown in Fig. 4. To assess the sensitivity of the choice of the theoretical distribution function, the model was also run with PDFs following a lognormal distribution (e.g. Liston, 2004):

$f(x ; \lambda, \zeta)=\frac{1}{x \zeta \sqrt{2}} e^{\left\{-\frac{1}{2}\left[\frac{\ln (x)-\lambda}{\zeta}\right]^{2}\right\}}$,

where

$\lambda=\ln (\mu)-\frac{1}{2} \zeta^{2}, \quad \zeta^{2}=\ln \left(1+\mathrm{CV}_{\mathrm{sd}}\right)$.

\subsection{Model evaluation}

The $\mathrm{CV}_{\text {sd }}$ was derived for $0.5 \mathrm{~km} \times 1 \mathrm{~km}$ areas based on the ALS snow depth data (Sect. 4.1) resampled to $10 \mathrm{~m} \times 10 \mathrm{~m}$ resolution. Each $0.5 \times 1 \mathrm{~km}$ area includes 500 to 5000 grid cells $10 \mathrm{~m} \times 10 \mathrm{~m}$, depending on the area masked out due to lakes or measurement errors. There were $>4000$ grid cells in $70 \%$ of the areas. Goodness-of-fit evaluations for the theoretical lognormal and gamma distributions applying the Anderson-Darling test in MATLAB (adtest.m, Stephens, 1974) were conducted for each distribution. Parameters for gamma (shape and rate) and lognormal $(\mu, \sigma)$ distributions were estimated by maximum likelihood as implemented in the MATLAB functions gamfit.m and lognfit.m.

The results of the permafrost model are evaluated with respect to the average MAGST and MAGT within each grid cell, as well as the fraction of sub-zero MAGST. For the evaluation runs, the model is forced with climatic data for the hydrological year corresponding to the observations. The performance in representing fractional permafrost distribution is 
evaluated at two field sites where arrays of 26 (Juvvasshøe) and 41 (Finse) data loggers have measured the distribution of ground surface temperatures at $2 \mathrm{~cm}$ depth within $500 \times 500 \mathrm{~m}$ areas for the hydrological year 2013 (Gisnås et al., 2014). The general lower limits of permafrost are compared to permafrost probabilities derived from BTS (basal temperature of snow) surveys (Haeberli, 1973; Lewkowicz and Ednie, 2004) conducted at Juvvasshøe and Dovrefjell (Isaksen et al., 2002). The model performance of MAGST is evaluated with data from 128 temperature data loggers located a few centimetres below the ground surface in the period 1999-2009 (Farbrot et al., 2008, 2011, 2013; Isaksen et al., 2008, 2011; Ødegaard et al., 2008). The loggers represent all vegetation classes used in the model and cover spatially large parts of Norway (Fig. 1, black dots). Four years of data from 25 boreholes (Isaksen et al., 2007, 2011; Farbrot et al., 2011, 2013) are used to evaluate modelled MAGT (Fig. 1, red dots). Tables of ground surface temperature loggers (Table S1) and boreholes used for validation (Table S2) are included in the Supplement.

\section{Data}

\subsection{Forcing and evaluation of the snow distribution scheme}

Wind speeds and directions during the snow accumulation season are calculated from the boundary layer wind speed and direction at $10 \mathrm{~m}$ above surface in the Norwegian Reanalysis Archive (NORA10) wind dataset. NORA10 is a dynamically downscaled dataset of ERA-40 to a spatial resolution of $10-11 \mathrm{~km}$, with hourly resolution of wind speed and direction (Reistad et al., 2011). The dataset is originally produced for wind fields over sea and underestimates the wind speeds at higher elevation over land (Haakenstad et al., 2012). A comparison with weather station data revealed that wind speeds above the treeline are underestimated by about $60 \%$ (Haakenstad et al., 2012). For these areas wind speeds in the forcing dataset have been linearly increased by $60 \%$.

The snow distribution scheme is derived from an ALS snow depth over the Hardangervidda mountain plateau in southern Norway (Melvold and Skaugen, 2013). The ALS survey is made along six transects, each covering a $0.5 \times 80 \mathrm{~km}$ area with nominal $1.5 \times 1.5 \mathrm{~m}$ ground point spacing. The survey was first conducted between 3 and 21 April 2008 and repeated in the period 21-24 April 2009. The snow cover was at a maximum during both surveys. A baseline scan was performed 21 September 2008 to obtain the elevation at minimum snow cover. The ALS data are presented in detail in Melvold and Skaugen (2013). Distributions of snow depth, represented as $\mathrm{CV}_{\mathrm{sd}}$, are calculated for each $0.5 \times 1 \mathrm{~km}$ area, based on the snow depth data resampled to $10 \mathrm{~m} \times 10 \mathrm{~m}$ resolution. About 400 cells of $0.5 \mathrm{~km} \times 1 \mathrm{~km}$ exist for each year, after lakes and areas below treeline are excluded.

The snow distribution scheme is validated with snow depth data obtained by ground penetrating radar (GPR) at Finse $\left(60^{\circ} 34^{\prime} \mathrm{N}, 7^{\circ} 32^{\prime} \mathrm{E} ; 1250-1332 \mathrm{~m}\right.$ a.s.1.) and Juvvasshøe $\left(61^{\circ} 41^{\prime} \mathrm{N}, 8^{\circ} 23^{\prime} \mathrm{E} ; 1374-1497 \mathrm{~m}\right.$ a.s.l.). The two field sites are both located in open, non-vegetated alpine landscapes with major wind re-distribution of snow. They differ with respect to mean maximum snow depth $(\sim 2 / \sim 1 \mathrm{~m})$, average winter wind speeds (7-8/10-14 $\mathrm{m} \mathrm{s}^{-1}$ ) and topography (very rugged at Finse, while steep, but less rugged, at Juvvasshøe). Snow surveys were conducted late March to April (2009, 2012-2014) around maximum snow depth, but when the snow pack was still dry. The GPR surveys at Finse are constrained to an area of $1 \times 1 \mathrm{~km}$, while at Juvvasshøe they cover several square kilometres, but with lower observation density. The GPR data from the end of the accumulation season in 2013 are presented in Gisnås et al. (2014), and the data series from the other years are obtained and processed following the same procedures, described in detail in Dunse et al. (2009). The propagation speed of the radar signal in dry snow was derived from the permittivity and the speed of light in vacuum, with the permittivity obtained from snow density using an empirical relation (Kovacs et al., 1995). The snow depths were determined from the two-way travel time of the reflection from the ground surface and the wave speed. Observations were averaged over $10 \mathrm{~m} \times 10 \mathrm{~m}$ grid cells, where grid cells containing less than three samples were excluded. The $\mathrm{CV}_{\text {sd }}$ for $1 \times 1 \mathrm{~km}$ areas are computed based on the $10 \mathrm{~m}$ resolution data.

\subsection{Permafrost model setup}

The climatic forcing of the permafrost model is daily gridded air temperature and snow depth data, called the seNorge dataset, provided by the Norwegian Meteorological Institute and the Norwegian Water and Energy Directorate. The dataset, available for the period 1961-2015, is based on air temperature and precipitation data collected at the official meteorological stations in Norway, interpolated to $1 \mathrm{~km} \times 1 \mathrm{~km}$ resolution applying optimal interpolation as described in Lussana et al. (2010). Snow depths are derived from the air temperature and precipitation data, using a snow algorithm accounting for snow accumulation and melt, temperature during snow fall and compaction (Engeset et al., 2004; Saloranta, 2012). Freezing (FDD $\left.{ }_{a}\right)$ and thawing $\left(\mathrm{TDD}_{\mathrm{a}}\right)$ degree days in the air are calculated as annual accumulated negative (FDD) and positive (TDD) daily mean air temperatures, and maximum annual snow depths $(\mu)$ are derived directly from the daily gridded snow depth data. The CryoGRID 1 model is implemented at $1 \mathrm{~km} \times 1 \mathrm{~km}$ resolution over the same grid as the seNorge dataset.

Soil properties and surface cover is kept as in Gisnås et al. (2013), with five land cover classes: forest, shrubs, open non-vegetated areas, mires and no data, based on CLC level 2 
Table 1. The three regression models for $\mathrm{CV}_{\mathrm{sd}}$ with in increasing number of predictors are calibrated with observed snow distributions from the ALS snow survey (left columns). $P$ values are $<10^{-6}$. The isolated snow distribution scheme is validated with independent snow distribution data collected with GPR snow surveys (right columns). Root mean square error (RMSE), coefficient of determination $\left(R^{2}\right)$ and Nash-Sutcliffe model efficiency (ME) are given for each model evaluation.

\begin{tabular}{|c|c|c|c|c|c|c|c|}
\hline \multirow[t]{2}{*}{$\mathrm{CV}_{\mathrm{sd}}=$} & & \multicolumn{3}{|c|}{ Fit of regression } & \multicolumn{3}{|c|}{$\mathrm{CV}_{\text {sd }}$, GPR survey } \\
\hline & & RMSE & $R^{2}$ & ME & RMSE & $R^{2}$ & ME \\
\hline Model 1 & $0.39+3.4 \times \mathrm{CV}_{S x}$ & 0.14 & 0.36 & 0.36 & 0.20 & 0.04 & -0.71 \\
\hline Model 2 & $0.31+3.1 \times \mathrm{CV}_{S x}+4.05 \times 10^{-4} \times z$ & 0.12 & 0.52 & 0.52 & 0.12 & 0.59 & 0.36 \\
\hline Model 3 & $0.40+3.1 \times \mathrm{CV}_{S x}+4.95 \times 10^{-4} \times z-0.0713 \times \mu$ & 0.12 & 0.55 & 0.55 & 0.09 & 0.62 & 0.61 \\
\hline
\end{tabular}

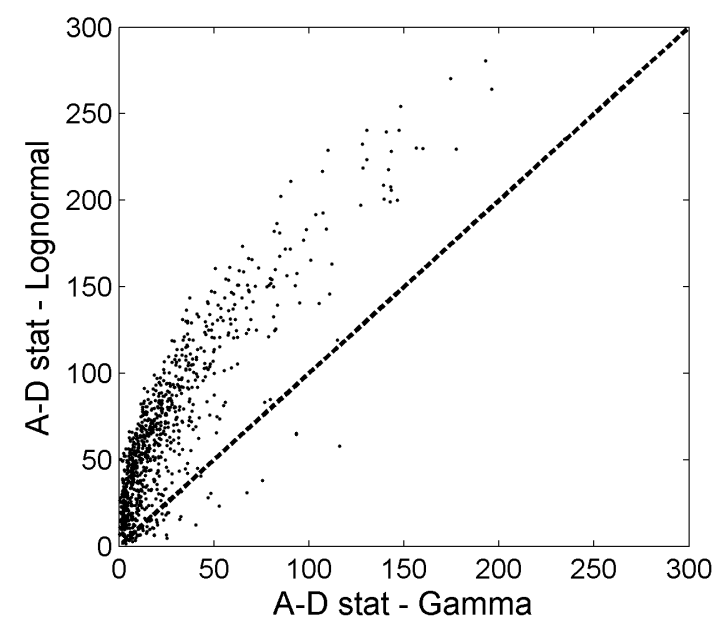

Figure 5. Scores from the Anderson-Darling test statistics for goodness of fit between theoretical gamma and lognormal distributions and the observed distribution within each $1 \times 1 \mathrm{~km}$ area in the ALS snow survey. Lower scores indicate better fit.

in the Norwegian Corine Land Cover map 2012 (AuneLundberg and Strand, 2010). Sub-grid distributions of snow are only implemented for open non-vegetated areas.

\section{Results}

\subsection{Observed snow distributions in mountain areas of Norway}

$\mathrm{CV}_{\text {sd }}$ within $1 \times 1 \mathrm{~km}$ areas in the ALS snow survey at Hardangervidda ranged from 0.15 to 1.14 , with mean and median of respectively 0.58 and 0.59 . According to the Anderson-Darling goodness-of-fit evaluations, 70 out of 932 areas had a snow distribution within the $5 \%$ significance interval of a gamma distribution, while only 1 area was within the $5 \%$ significance interval of a lognormal distribution. Although the null hypothesis rejected more than $90 \%$ of the sample distributions, the Anderson-Darling test score was all over lower for the gamma distribution, indicating that the observed snow distributions are closer to a gamma than
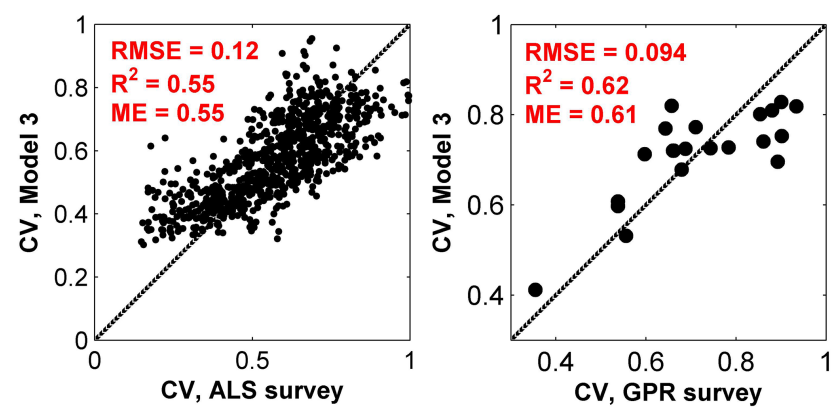

Figure 6. Left panel: fit of the regression Model 3 for $\mathrm{CV}_{\text {sd }}$, calibrated with $\mathrm{CV}_{\mathrm{sd}}$ derived from the ALS snow survey. Right panel: the model performance is evaluated with independent ground penetrating radar (GPR) snow surveys from at Finse and Juvvasshøe.

to a lognormal theoretical distribution (Fig. 5). For lower lying areas with less varying topography and shallower snow depths, in particular in the eastern parts of Hardangervidda, the observed snow distributions were similarly close to both distributions. In higher elevated parts with more snow to the west of the plateau the snow distributions were much closer to a gamma distribution. Based on these findings a gamma distribution was used in the main model runs, while a model run with lognormal distributions of snow was made to evaluate the sensitivity towards the choice of the distribution function (Sect. 3.2).

\subsection{Evaluation of the snow distribution scheme}

Three regression models for $\mathrm{CV}_{\mathrm{sd}}$ as a function of the terrain-based parameter $S x$, elevation $(z)$ and mean maximum snow depth $(\mu)$ were calibrated with the snow distribution data from the ALS snow survey over the Hardangervidda mountain plateau (Table 1). Model 1 results in a RMSE of only 0.14 . However, the correlations of the distributions are significantly improved by including elevation as predictor (Model $2 ; R^{2}=0.52$ ). Including maximum snow depth as additional predictor (Model 3 ) improves the model slightly to $R^{2}=0.55$ (Fig. 6). The distribution of $\mathrm{CV}_{\mathrm{sd}}$ (example of Model 3 in Fig. 7, left panel) shows increased values in areas of rougher topography (western side of Norway) and higher 

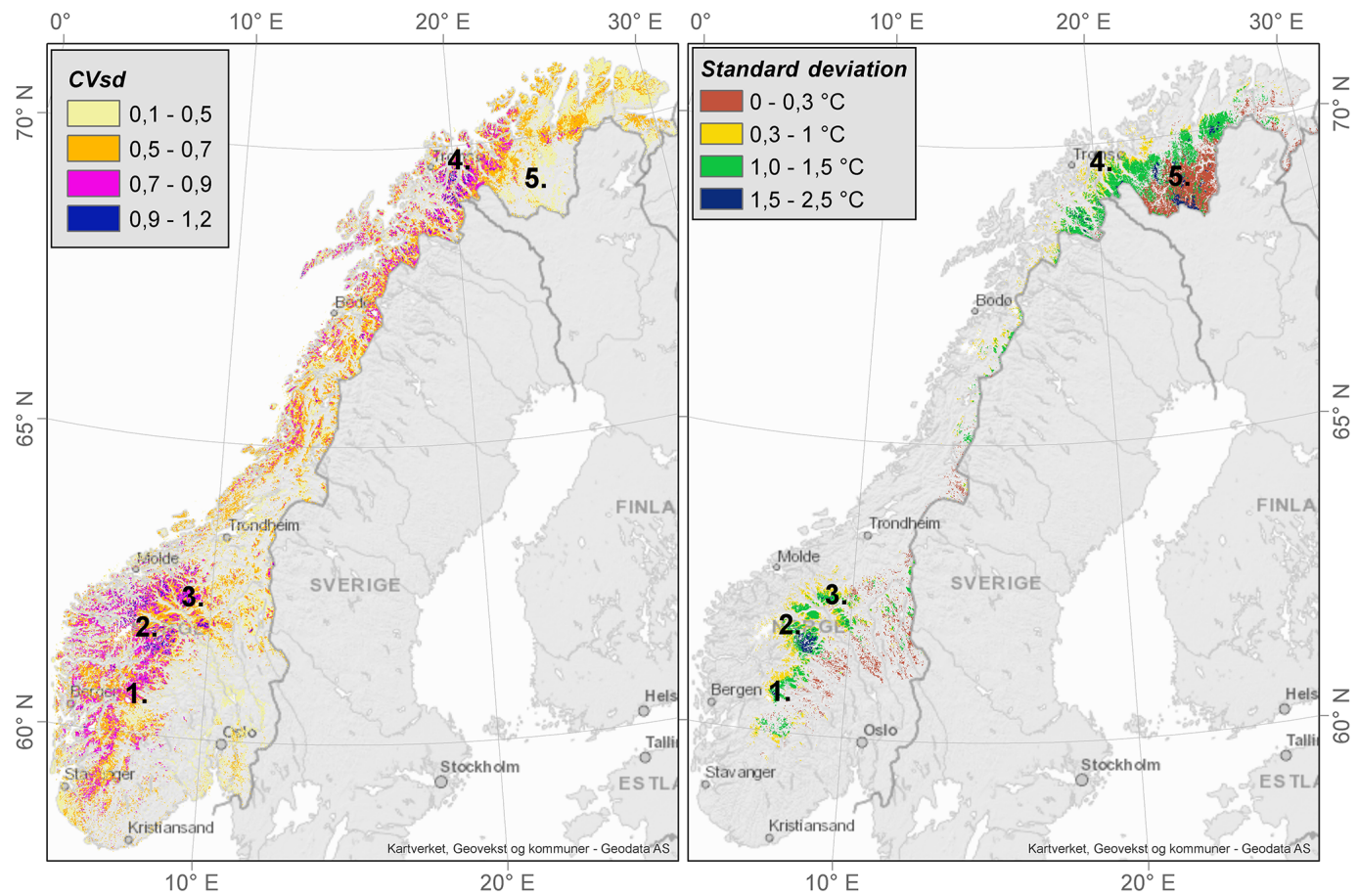

Figure 7. Left panel: distribution of modelled $\mathrm{CV}_{\mathrm{sd}}$ in non-vegetated areas of Norway with Model 3. $\mathrm{CV}_{\mathrm{sd}}$ increases in areas of rougher topography (western side of Norway) and higher elevations (central part following the Scandes). Right panel: standard deviation of modelled MAGT for areas of modelled permafrost. Sites mentioned in the text: (1) Finse, south of Hallingskarvet; (2) Juvvasshøe in Jotunheimen; (3) Dovrefjell; (4) the Lyngen Alps; and (5) Finnmark.

elevations (central part following the Scandes), with maximum $\mathrm{CV}_{\text {sd }}$ up to 1.2 in the Lyngen Alps and at peaks around Juvvasshøe (Fig. 1, site 2 and 4). The lowest values of $0.2-$ 0.3 are modelled in larger valleys in south eastern Norway, where elevations are lower and topography gentler.

The regression models for $\mathrm{CV}_{\mathrm{sd}}$ are validated with data from GPR snow surveys at Juvvasshøe and Finse (Table 1). The correlation for Model 1 is poor, with $R^{2}=0.04$ and Nash-Sutcliffe model efficiency $(\mathrm{ME})=-0.7$ (Table 1 ). Model 2 improves the correlation significantly, while the best fit is obtained with Model 3 (Fig. 6, RMSE $=0.094$, $R^{2}=0.62$ and $\left.\mathrm{ME}=0.61\right)$. The improvement in Model 3 compared to Model 2 is more pronounced in the validation than in the fit of the regression models and is mainly a result of better representation of the highest $\mathrm{CV}_{\text {sd }}$ values. The validation area at Juvvasshøe is located at higher elevations than what is represented in the ALS snow survey dataset and undergoes extreme redistribution by wind. The representation of extreme values, therefore, has a high impact in the validation run.

\subsection{Modelled ground temperatures for mainland Norway}

The main results presented in this section are based on the model run with 100 realisations per grid cell, applying gamma distributions over the $\mathrm{CV}_{\text {sd }}$ from Model 3. The main results are given as averages over the 30-year period 19812010. According to the model run, in total $25400 \mathrm{~km}^{2}$ $(7.8 \%)$ of the Norwegian mainland is underlain by permafrost in an equilibrium situation with the climate over the 30-year period 1981-2010 (Fig. 1). Of the land area, 12\% features sub-zero ground temperatures in more than $10 \%$ of a $1 \mathrm{~km}$ grid cell and is classified as sporadic $(4.4 \%)$, discontinuous $(3.2 \%)$ or continuous $(4.3 \%)$ permafrost (Fig. 1). In comparison, the model run without a sub-grid variation results in a permafrost area of only $13460 \mathrm{~km}^{2}$, corresponding to $4.1 \%$ of the model domain (Table 2). The difference is illustrated for Juvvasshøe (Fig. 8a) and Dovrefjell (Fig. 8c), where the sub-grid model reproduces very well the observed lower limit of permafrost based on borehole temperatures and BTS surveys. In contrast, the model without sub-grid variability indicates a hard line for the permafrost limit at much higher elevations (Fig. 8b and d). At Juvvasshøe, the model without sub-grid distribution still reproduces the permafrost limit to some extent because of the large elevation gradient. At Dovrefjell, where the topography is much gentler, the difference between the models is much larger and the approach without sub-grid distribution is not capable of reproducing the observed permafrost distribution. The modelled permafrost area for model runs applying the other mod- 
els for $\mathrm{CV}_{\text {sd }}$ and theoretical distribution functions are summarised in Table 2.

The standard deviations of the modelled sub-grid distribution of MAGT range from 0 to $2.5^{\circ} \mathrm{C}$ (Fig. 7, right panel). The highest standard deviation values are found in the Jotunheimen area, where modelled sub-grid variability of MAGT is up to $5^{\circ} \mathrm{C}$. Also, at lower elevations in southeastern parts of Finnmark standard deviations exceed $1.5^{\circ} \mathrm{C}$. Here, the $\mathrm{CV}_{\text {sd }}$ values are below 0.4 , but because of cold $\left(\mathrm{FDD}_{\mathrm{a}}<-2450^{\circ} \mathrm{C}\right)$ and dry $(\max \mathrm{SD}<0.5 \mathrm{~m})$ winters even small variations in the snow cover have large effects on the ground temperatures.

Close to $70 \%$ of the modelled permafrost is situated within open, non-vegetated areas above treeline, classified as mountain permafrost according to Gruber and Haeberli (2009). This is the major part of the permafrost extent both in northern and southern Norway. In northern Norway the model results indicate that the lower limit of continuous and sporadic mountain permafrost decreases eastwards from 1200 and $700 \mathrm{~m}$ a.s.l. in the west to 500 and $200 \mathrm{~m}$ in the east respectively. In southern Norway, the southernmost location of continuous mountain permafrost is in the mountain massif of Gaustatoppen at $59.8^{\circ} \mathrm{N}$, with continuous permafrost above $1700 \mathrm{~m}$ a.s.l. and discontinuous permafrost down to $1200 \mathrm{~m}$ a.s.l. In more central southern Norway the continuous mountain permafrost reaches down to $1600 \mathrm{~m}$ a.s.l. in the western Jotunheimen and Hallingskarvet, and down to $1200 \mathrm{~m}$ a.s.l. in the east at the Swedish border. The sporadic mountain permafrost extends around $200 \mathrm{~m}$ further down both in the western and eastern parts.

\subsection{Evaluation of CryoGRID 1 with sub-grid snow distribution scheme}

The observed and modelled $\mathrm{CV}_{\text {sd }}$ values at the field sites were 0.85 and 0.80 at Juvvasshøe, and 0.71 and 0.77 at Finse. At Juvvasshøe the observed fraction of loggers with MAGST below $0{ }^{\circ} \mathrm{C}$ was $77 \%$, while the model result indicates an aerial fraction of $64 \%$. Similarly, at Finse the observed negative MAGST fraction was $30 \%$, while the model indicates $32 \%$. The measured ranges of MAGST within the $1 \mathrm{~km} \times 1 \mathrm{~km}$ areas were relatively well reproduced by the model (Table 3 ). The average MAGST within each field area was also improved compared to a model without a sub-grid representation of snow (Table 3 , in parenthesis).

Of the observed MAGSTs, $58 \%$ are captured by the modelled range of MAGST for the corresponding grid cell and $87 \%$ within $1{ }^{\circ} \mathrm{C}$ outside the range given by the distribution. The overall correlation between observed MAGST and average modelled MAGST for a grid cell is fairly good with RMSE, $R^{2}$ and $\mathrm{ME}$ of $1.3^{\circ} \mathrm{C}, 0.65$ and 0.37 respectively (Fig. 9, left panel). The measured MAGT was within the range of modelled MAGTs in all boreholes except one, where MAGT deviates $0.2^{\circ} \mathrm{C}$ outside the range. All the average modelled MAGTs are within $\pm 1.6^{\circ} \mathrm{C}$ of observations, while
$90 \%$ are within $1^{\circ} \mathrm{C}$. The RMSE between the observed and modelled average MAGT is $0.6^{\circ} \mathrm{C}$ (Fig. 9, right panel).

The evaluation of the model runs with all three $\mathrm{CV}_{\mathrm{sd}}$ models, as well as lognormal instead of gamma distribution functions, is summarised in Table 2. The highest correlation between observed and mean MAGST and MAGT was obtained by Model 3, but Model 2 yielded similar correlations. All three model runs capture $58 \%$ of the observed MAGST and more than $98 \%$ of the observed MAGT within the temperature range of the corresponding grid cell. The total area of modelled permafrost is $9 \%$ less when applying the simplest snow distribution model (Model 1) compared to the reference model (Model 3), while the same model without any sub-grid distribution results in $47 \%$ less permafrost area. With a lognormal distribution the modelled permafrost area is $18 \%$ less (Model 3) than with a gamma distribution.

\section{Discussion}

\subsection{The effect of a statistical representation of sub-grid variability in a regional permafrost model}

The total distribution of modelled permafrost with the subgrid snow scheme corresponds to $7.8 \%$ of the Norwegian land area, while the modelled permafrost area without a subgrid representation of snow only comprises $4 \%$. This large difference in total modelled permafrost area stems exclusively from differences in the amount of modelled permafrost in mountains above the treeline. In these areas the snow distribution is highly asymmetric and a majority of the area has below average snow depths. Because of the nonlinearity in the insulating effect of snow cover, the mean ground temperature of a grid cell is not the same as, or even far from, the ground temperature below the average snow depth. Often, the majority of the area in high, wind-exposed mountains is nearly bare blown with most of the snow blown into terrain hollows. Consequently, most of the area experiences significantly lower average ground temperatures than with an evenly distributed, average depth snow cover. In mountain areas with a more gentle topography and relatively small spatial temperature variations, an evenly distributed snow depth will result in large biases in modelled permafrost area, as illustrated at Dovrefjell in Fig. 8. This study provides clear evidence that the sub-grid variability of snow depths should be included in model approaches targeting the ground thermal regime and permafrost distribution.

The model reproduces the large range of variation in subgrid ground temperatures, with standard deviations up to $2.5^{\circ} \mathrm{C}$, coincident to the observed small-scale variability of up to $6^{\circ} \mathrm{C}$ within a single grid cell (Gubler et al., 2011; Gisnås et al., 2014). Inclusion of sub-grid variability of snow depths in the model provides a more adequate representation of the gradual transition from permafrost to permafrost-free areas in alpine environments and, thus, a better estimation 


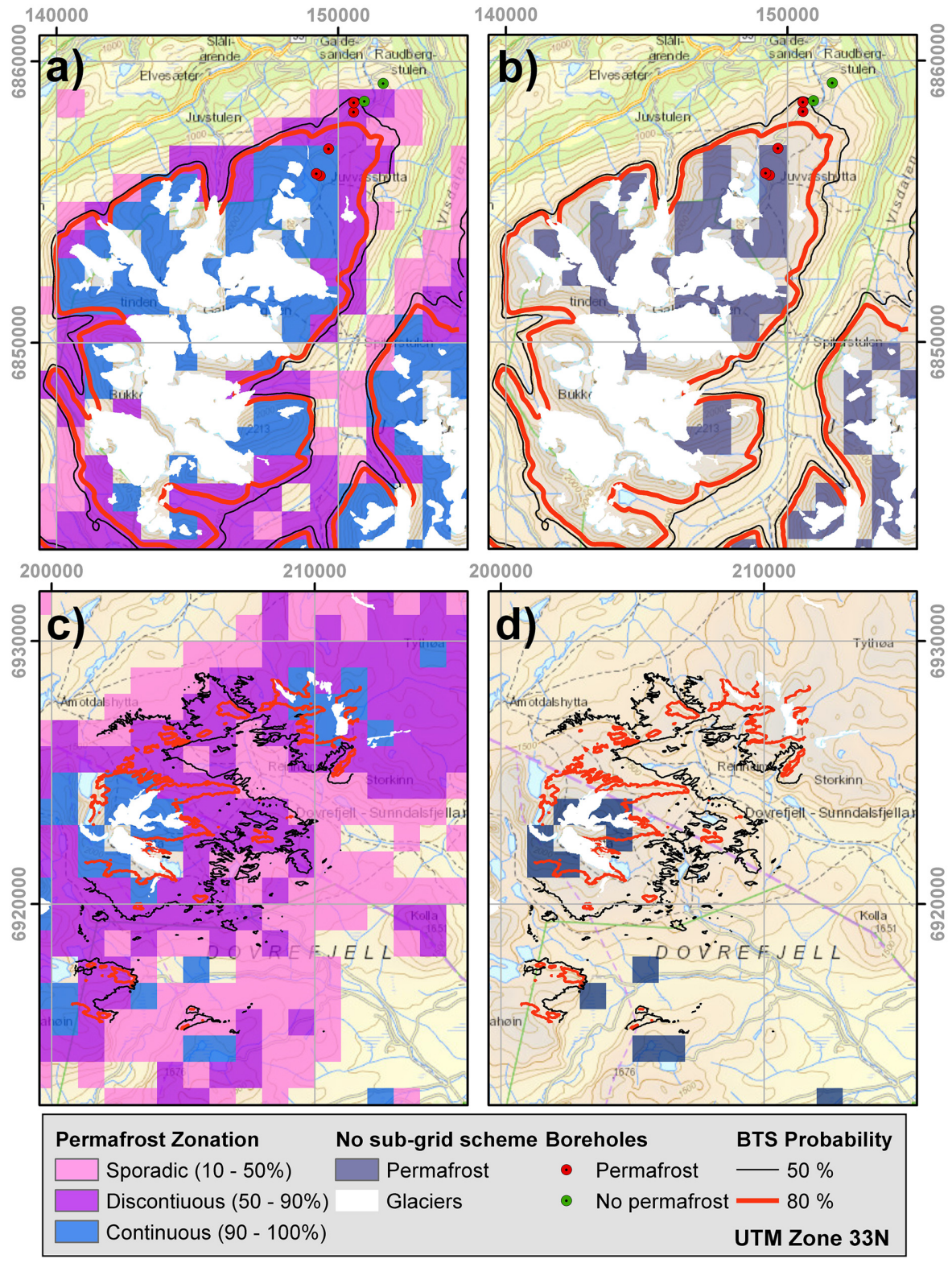

Figure 8. Distribution of permafrost at Juvvasshøe in Jotunheimen (a, b) and at Dovrefjell (c, d), modelled as permafrost zones applying the sub-grid approach (left panels) compared to the modelled mean annual ground temperature (MAGT) without a sub-grid approach (right panels). Lower limits of $50 \%$ and $80 \%$ probability of permafrost derived from BTS surveys are shown as black and red contour lines respectively. Borehole locations with permafrost (red) and seasonal frost (green) are shown as dots in the map at Juvvasshøe.

of permafrost area. In a warming climate, a model without such a sub-grid representation would respond with an abrupt decrease in permafrost extent. In reality, bare blown areas with mean annual ground temperatures of $-6^{\circ} \mathrm{C}$ need a large temperature increase to thaw. Increased precipitation as snow would also warm the ground; however, bare blown areas may still be bare blown with increased snow accumulation during winter. A statistical snow distribution reproduces this effect, also with an increase in mean snow depth.
CryoGRID1 is a simple modelling scheme delivering a mean annual ground temperature at the top of the permanently frozen ground based on near-surface meteorological variables, under the assumption that the ground thermal regime is in equilibrium with the applied surface forcing. This is a simplification, and the model cannot reproduce the transient evolution of ground temperatures and is therefore not suitable for future climate predictions. However, it has proven to capture the regional patterns of permafrost reasonably well (Gisnås et al., 2013; Westermann et al., 2013). 
Table 2. The model performance is evaluated with respect to the mean annual ground surface temperature (MAGST) and the mean annual temperature at the depth of the active layer or seasonal freezing layer (MAGT). Modelled average MAGST or MAGT over a grid cell is compared to more than 100 GST logger locations and 25 boreholes. The location of the GST loggers and boreholes are shown in Fig. 1. Modelled permafrost distribution is given in total areas and as percentage of the model domain, corresponding to the Norwegian mainland area.

\begin{tabular}{|c|c|c|c|c|c|c|c|c|c|}
\hline & & \multicolumn{6}{|c|}{ Permafrost model evaluation } & & \\
\hline & & \multicolumn{3}{|c|}{ MAGST, GST loggers } & \multicolumn{3}{|c|}{ MAGT, boreholes } & \multicolumn{2}{|c|}{ Modelled permafrost area } \\
\hline & & RMSE & $R^{2}$ & ME & RMSE & $R^{2}$ & ME & $\left(\mathrm{km}^{2}\right)$ & $(\%)$ \\
\hline \multicolumn{2}{|c|}{ No sub-grid variation } & 1.57 & 0.65 & -0.56 & 1.19 & 0.62 & -1.90 & 13462 & 4.1 \\
\hline \multirow{4}{*}{ 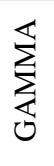 } & $\mathrm{CV}_{\mathrm{sd}}=0.6$ & 1.37 & 0.64 & 0.06 & 0.77 & 0.66 & 0.22 & 23571 & 7.3 \\
\hline & Model 1 & 1.36 & 0.63 & 0.12 & 0.77 & 0.66 & 0.11 & 23147 & 7.1 \\
\hline & Model 2 & 1.29 & 0.65 & 0.31 & 0.65 & 0.71 & 0.62 & 23674 & 7.3 \\
\hline & Model 3* & 1.29 & 0.65 & 0.38 & 0.67 & 0.71 & 0.68 & 25407 & 7.8 \\
\hline \multirow{3}{*}{ Zֶ } & Model 1 & 1.40 & 0.64 & -0.06 & 0.87 & 0.67 & -0.25 & 19975 & 6.2 \\
\hline & Model 2 & 1.38 & 0.65 & 0.01 & 0.82 & 0.69 & 0.09 & 20067 & 6.2 \\
\hline & Model 3 & 1.36 & 0.65 & 0.06 & 0.78 & 0.69 & 0.22 & 20889 & 6.2 \\
\hline
\end{tabular}

* Reference model run.

Table 3. Observed and modelled values for the coefficient of variation for maximum snow depth $\left(\mathrm{CV}_{\mathrm{sd}}\right)$ and spatial distributions of mean annual ground surface temperature (MAGST) at the field sites at Finse and Juvvasshøe. The MAGST modelled without a sub-grid distribution of snow is given in parenthesis.

\begin{tabular}{llllll}
\hline & \multicolumn{2}{c}{ Juvvasshøe } & & \multicolumn{2}{c}{ Finse } \\
\cline { 2 - 3 } \cline { 5 - 6 } & Observed & Modelled & & Observed & Modelled \\
\hline $\mathrm{CV}_{\text {sd }}$ & 0.85 & 0.80 & & 0.71 & 0.77 \\
${\text { MAGST }<0{ }^{\circ} \mathrm{C}}$ & $77 \%$ & $64 \%$ & & $30 \%$ & $32 \%$ \\
MAGST $_{\text {min }}$ & $-1.8^{\circ} \mathrm{C}$ & $-2.6^{\circ} \mathrm{C}$ & & $-1.9^{\circ} \mathrm{C}$ & $-1.6^{\circ} \mathrm{C}$ \\
MAGST $_{\text {max }}$ & $1.0^{\circ} \mathrm{C}$ & $0.8^{\circ} \mathrm{C}$ & & $2.7^{\circ} \mathrm{C}$ & $1.0^{\circ} \mathrm{C}$ \\
MAGST $_{\text {avg }}$ & $-0.5^{\circ} \mathrm{C}$ & $-0.5^{\circ} \mathrm{C}\left(0.8^{\circ} \mathrm{C}\right)$ & & $0.8^{\circ} \mathrm{C}$ & $0.2^{\circ} \mathrm{C}\left(1.3^{\circ} \mathrm{C}\right)$ \\
\hline
\end{tabular}

Because of the simplicity, it is computationally efficient and suitable for doing test studies like the one presented in this paper and in similar studies (Westermann et al., 2015).

For the model evaluation with measured ground temperatures in boreholes (Sect. 5.4), the modelled temperatures are forced with data for the hydrological year corresponding to the observations. Because of the assumption of an equilibrium situation in the model approach, such a comparison can be problematic as many of the boreholes have undergone warming during the past decades. However, with the majority of the boreholes located in bedrock or coarse moraine material with relatively high conductivity, the lag in the climate signal is relatively small at the top of the permafrost. The lag will also vary from borehole to borehole, depending on the ground thermal properties. Since we use data distributed over larger areas and longer time periods, including a large range of situations, the effect is mainly evident in terms of a larger statistical spread and not a systematic error.

The large amount of field observations used for calibration and evaluation in this study is mainly conducted in alpine mountain areas. The large spatial variation in winter snow depths is a major controlling factor also of the ground temperatures in peat plateaus and palsa mires and is a driving factor in palsa formation (Seppälä, 2011). The sub-grid effect of snow should therefore also be implemented for mire areas, where comparable datasets are lacking.

\subsection{Model sensitivity}

The sensitivity of the $\mathrm{CV}_{\text {sd }}$ model to the modelled ground temperatures is relatively low, with only $9 \%$ variation in permafrost area, although the performance of the snow distribution scheme varies significantly between the models when evaluated with GPR snow surveys (Table 1). In comparison, a lognormal instead of a gamma distribution function reduces the permafrost area by $18 \%$ (Table 2 ). The choice of distribution function therefore seems to be of greater importance than the fine tuning of a model for $\mathrm{CV}_{\text {sd }}$. This result contradicts the conclusions by Luce and Tarboton (2004), which suggest that the parameterization of the distribution function is more important than the choice of distribution model. With 

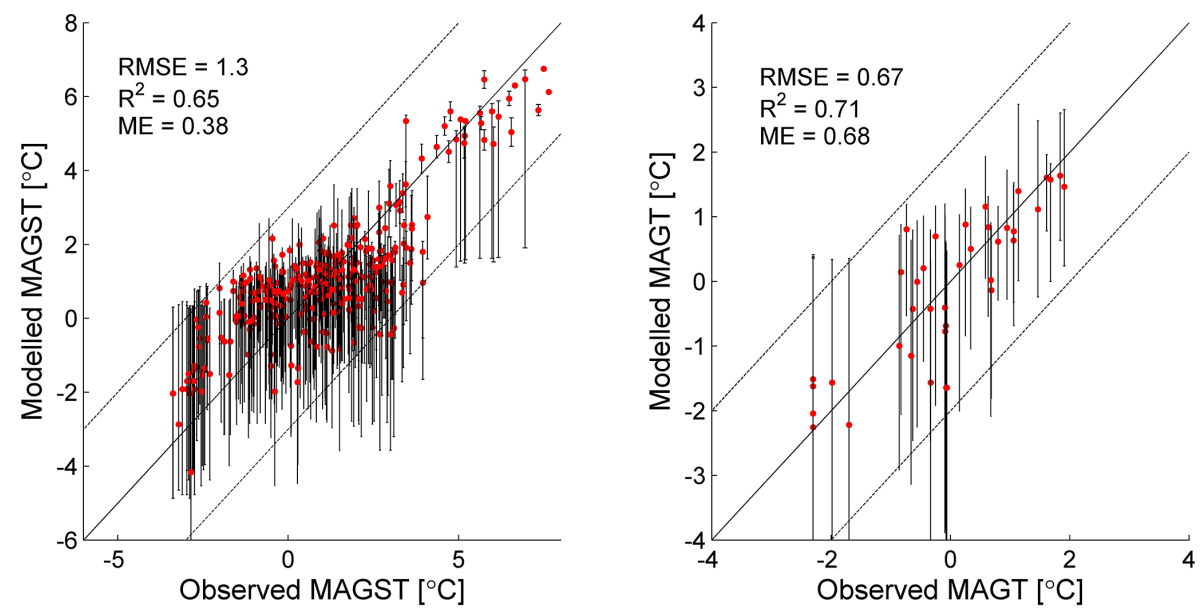

Figure 9. Correlation between modelled and observed MAGST (left panel) and MAGT at the top of permafrost (right panel). The dotted line indicates $\pm 2{ }^{\circ} \mathrm{C}$ of the $1: 1$ line (black line). The vertical bars indicate the variation of modelled temperatures within the grid cell, and the red dots indicate the mean temperature.

a focus on hydrology and snow cover depletion curves, equal importance was given to both the deeper and shallower snow depths in the mentioned study. In contrast, an accurate representation of the shallowest snow depths is crucial for modelling the ground thermal regime. The low thermal conductivity of snow results in a disconnection of ground surface and air temperatures at snow packs thicker than $0.5-1 \mathrm{~m}$, depending on the physical properties of the snow pack and the surface roughness (Haeberli, 1973). In wind-exposed areas prone to heavy redistribution, large fractions of the area will be entirely bare blown (Gisnås et al., 2014). These are the areas of greatest importance for permafrost modelling. In order to reproduce the gradual transition in the discontinuous permafrost zone, where permafrost is often only present at bare blown ridges, shallow snow covers must be satisfactorily represented. Compared to a gamma function, a lognormal distribution function to a larger degree underestimates the fraction of shallow snow depths, resulting in a less accurate representation of this transition.

Several studies include statistical representations of the sub-grid variability of snow in hydrological models, most commonly applying a two- or three-parameter lognormal distribution (e.g. Donald et al., 1995; Liston, 2004; Pomeroy et al., 2004; Nitta et al., 2014). Observed snow distributions within $1 \times 1 \mathrm{~km}$ in the ALS snow survey presented in this paper are closer to a gamma than to a lognormal distribution, supporting the findings by Skaugen (2007) and Winstral and Marks (2014) which were both conducted in non-forested alpine environments. However, the difference is not substantial in all areas; the two distributions can provide near-equal fit in eastern parts of the mountain plateau where the terrain is gentler and the wind speeds are lower. We suggest that the choice of distribution function of snow is important in model applications for the ground thermal regime and recommend the use of gamma distribution for non-vegetated high alpine areas prone to heavy redistribution of snow.

While a gamma distribution offers improvements over a lognormal distribution, the bare blown areas are still not sufficiently represented. One attempt to solve this is to include a third parameter for the "snow-free fraction" (e.g. Kolberg et al., 2006; Kolberg and Gottschalk, 2010). We made an attempt to calibrate such a parameter for this study, but no correlations to any of the predictors were found. It is also difficult to determine a threshold depth for "snow-free" areas in ALS data resampled to $10 \mathrm{~m}$ resolution, where the uncertainty of the snow depth observations are in the order of $10 \mathrm{~cm}$ (Melvold and Skaugen, 2013).

In this study a high number of realisations could be run per grid cell because of the low computational cost of the model. To evaluate the sensitivity of sampling density, the number of realisations was reduced from 100 to 10 per grid cell. This resulted is a $2.6 \%$ increase in total modelled permafrost area relative to the reference model run. This demonstrates that a statistical downscaling of ground temperatures as demonstrated in this study is robust and significantly improves the model results with only a few additional model realisations per grid cell.

\section{Conclusions}

We present a modelling approach to reproduce the variability of ground temperatures within the scale of $1 \mathrm{~km}^{2}$ grid cells based on probability distribution functions over corresponding seasonal maximum snow depths. The snow distributions are derived from climatic parameters and terrain parameterisations at $10 \mathrm{~m}$ resolution and are calibrated with a largescale dataset of snow depths obtained from laser scanning. The model results are evaluated with independent observa- 
tions of snow depth distributions, ground surface temperature distributions and ground temperatures. From this study the following conclusions can be drawn.

- The total modelled permafrost area in an equilibrium with the average climate for the period 1981-2010 is $25400 \mathrm{~km}^{2}$. This corresponds to $7.8 \%$ of the Norwegian mainland.

- The model simulation without a sub-grid representation of snow produces almost $50 \%$ less permafrost.

- Due to the nonlinear insulating effect of snow in combination with asymmetric snow distributions within each grid cell, the spatial average ground temperature in a $1 \mathrm{~km}^{2}$ area cannot be determined based on the average snow cover for that area.

- Observed variations in ground surface temperatures from two logger arrays with 26 and 41 loggers respectively are very well reproduced, with estimated fractions of sub-zero MAGST within $\pm 10 \%$.

- Of the observed mean annual temperatures at top of permafrost in the boreholes, $94 \%$ are within the modelled ground temperature range for the corresponding grid cell, and mean modelled temperature of the grid cell reproduces the observations with an accuracy of $1.5^{\circ} \mathrm{C}$ or better.

- The sensitivity of the model to $\mathrm{CV}_{\mathrm{sd}}$ is relatively low compared to the choice of theoretical snow distribution function. Both are minor effects compared to the effect of running the model without a sub-grid distribution.

- The observed $\mathrm{CV}_{\mathrm{sd}}$ within $1 \mathrm{~km}^{2}$ grid cells in the Hardangervidda mountain plateau varies from 0.15 to 1.15 , with an average $\mathrm{CV}_{\mathrm{sd}}$ of 0.6. The observed $\mathrm{CV}_{\text {sd }}$ values are nearly identical at the end of the accumulation seasons in 2008 and 2009.

- The distributions are generally closer to a theoretical gamma distribution than to a lognormal distribution, in particular in areas of very rough topography, thicker snow cover and higher average winter wind speeds.

In areas subject to snow redistribution, the average ground temperature of a $1 \mathrm{~km}^{2}$ grid cell must be determined based on the distribution and not the overall average of snow depths within the grid cell. Modelling the full range of ground temperatures present over small distances facilitates a better representation of the gradual transition from permafrost to nonpermafrost areas and most likely a more accurate response to climate warming. This study demonstrates that accounting for the sub-grid variability of snow depths can strongly improve model estimates of the ground thermal regime and permafrost distribution alpine conditions.

\section{The Supplement related to this article is available online at doi:10.5194/tc-10-1201-2016-supplement.}

Acknowledgements. This study is part of the CryoMet project (project number 214465; funded by the Norwegian Research Council) and the ESCYMO project (project number 244024; funded by the Norwegian Research Council). The field campaigns at Finse was partly founded by the hydropower companies Statkraft and ECO, while the field work at Juvvasshøe was done in collaboration with Ketil Isaksen (Norwegian Meteorological Institute). The Norwegian Meteorological Institute provided the NORA10 wind data and the seNorge gridded temperature data. The Norwegian Water and Energy Directorate provided the seNorge gridded snow depth data and the ALS snow survey at Hardangervidda. Kolbjørn Engeland gave valuable comments to the statistical analysis presented in the manuscript. We gratefully acknowledge the support of all mentioned individuals and institutions.

Edited by: M. Krautblatter

\section{References}

Aune-Lundberg, L. and Strand, G.-H.: CORINE Land Cover 2006, The Norwegian CLC2006 project, Report from the Norwegian Forest and Landscape Institute 11/10, Norwegian Forest and Landscape Institute, Ås, 14 pp., 2010.

Clark, M. P., Hendrikx, J., Slater, A. G., Kavetski, D., Anderson, B., Cullen, N. J., Kerr, T., Hreinsson, E. Ö., and Woods, R. A.: Representing spatial variability of snow water equivalent in hydrologic and land-surface models: A review, Water Resour. Res., 47, W07539, doi:10.1029/2011WR010745, 2011.

Donald, J. R., Soulis, E. D., Kouwen, N., and Pietroniro, A.: A Land Cover-Based Snow Cover Representation for Distributed Hydrologic Models, Water Resour. Res., 31, 995-1009, 1995.

Dunse, T., Schuler, T. V., Hagen, J. O., Eiken, T., Brandt, O., and Høgda, K. A.: Recent fluctuations in the extent of the firn area of Austfonna, Svalbard, inferred from GPR, Ann. Glaciol., 50, 155-162, 2009.

Engeset, R., Tveito, O. E., Alfnes, E., Mengistu, Z., Udnæs, C., Isaksen, K., and Førland, E. J.: Snow map System for Norway, XXIII Nordic Hydrological Conference, 8-12 August, Tallin, Estonia, NHP report, 48, 112-121, 2004.

Farbrot, H., Isaksen, K., and Etzelmüller, B.: Present and past distribution of mountain permafrost in Gaissane Mountains, Northern Norway, in: Proceeding of the Ninth International Conference on Permafrost, 28 June-3 July 2008, Fairbanks, Alaska, 427-432, 2008.

Farbrot, H., Hipp, T. F., Etzelmüller, B., Isaksen, K., Ødegård, R. S., Schuler, T. V., and Humlum, O.: Air and Ground Temperature Variations Observed along Elevation and Continentality Gradients in Southern Norway, Permafrost Periglac., 22, 343-360, 2011.

Farbrot, H., Isaksen, K., Etzelmüller, B., and Gisnås, K.: Ground Thermal Regime and Permafrost Distribution under a Changing Climate in Northern Norway, Permafrost Periglac., 24, 20-38, 2013. 
Fiddes, J. and Gruber, S.: TopoSUB: a tool for efficient large area numerical modelling in complex topography at sub-grid scales, Geosci. Model Dev., 5, 1245-1257, doi:10.5194/gmd-5-12452012, 2012.

Gisnås, K., Etzelmuller, B., Farbrot, H., Schuler, T. V., and Westermann, S.: CryoGRID 1.0: Permafrost Distribution in Norway estimated by a Spatial Numerical Model, Permafrost Periglac., 24, 2-19, 2013.

Gisnås, K., Westermann, S., Schuler, T. V., Litherland, T., Isaksen, K., Boike, J., and Etzelmüller, B.: A statistical approach to represent small-scale variability of permafrost temperatures due to snow cover, The Cryosphere, 8, 2063-2074, doi:10.5194/tc-82063-2014, 2014.

Goodrich, L. E.: The influence of snow cover on the ground thermal regime, Can. Geotech. J., 19, 421-432, 1982.

Gruber, S. and Haeberli, W.: Mountain permafrost, in: Permafrost Soils, edited by: Margesin, R., Springer, Berlin ,Heidelberg, 3344, 2009.

Gubler, S., Fiddes, J., Keller, M., and Gruber, S.: Scaledependent measurement and analysis of ground surface temperature variability in alpine terrain, The Cryosphere, 5, 431-443, doi:10.5194/tc-5-431-2011, 2011.

Haakenstad, H., Reistad, M., Haugen, J. E., and Breivik, Ø.: Update of the NORA10 hindcast archive for 2011 and study of polar low cases with the WRF model, no report no. 17/2012, met, Oslo, 2012.

Haeberli, W.: Die Basis-Temperatur der winterlichen Schneedecke als möglicher Indikator für die Verbreitung von Permafrost in den Alpen, Z. Gletscherk. Glazialgeol., 9, 221-227, 1973.

Hipp, T.: Mountain Permafrost in Southern Norway. Distribution, Spatial Variability and Impacts of Climate Change, PhD, Faculty of Mathematics and Natural Sciences, Department of Geosciences, University of Oslo, Osloa, 166 pp., 2012.

Isaksen, K., Hauck, C., Gudevang, E., Ødegård, R. S., and Sollid, J. L.: Mountain permafrost distribution in Dovrefjell and Jotunheimen, southern Norway, based on BTS and DC resistivity tomography data, Norsk Geogr. Tidsskr., 56, 122-136, 2002.

Isaksen, K., Sollid, J. L., Holmlund, P., and Harris, C.: Recent warming of mountain permafrost in Svalbard and Scandinavia, J. Geophys. Res., 112, F02S04, doi:10.1029/2006jf000522, 2007.

Isaksen, K., Farbrot, H., Blikra, L., Johansen, B., Sollid, J., and Eiken, T.: Five year ground surface temperature measurements in Finnmark, Northern Norway., Ninth International Conference on Permafrost, Fairbanks, Alaska, 789-794, 2008.

Isaksen, K., Ødegård, R. S., Etzelmüller, B., Hilbich, C., Hauck, C., Farbrot, H., Eiken, T., Hygen, H. O., and Hipp, T. F.: Degrading Mountain Permafrost in Southern Norway: Spatial and Temporal Variability of Mean Ground Temperatures, 1999-2009, Permafrost Periglac., 22, 361-377, 2011.

Kolberg, S. A. and Gottschalk, L.: Updating of snow depletion curve with remote sensing data, Hydrol. Process., 20, 23632380, 2006.

Kolberg, S. A. and Gottschalk, L.: Interannual stability of grid cell snow depletion curves as estimated from MODIS images, Water Resour. Res., 46, W11555, doi:10.1029/2008WR007617, 2010.

Kolberg, S., Rue, H., and Gottschalk, L.: A Bayesian spatial assimilation scheme for snow coverage observations in a gridded snow model, Hydrol. Earth Syst. Sci., 10, 369-381, doi:10.5194/hess10-369-2006, 2006.
Kovacs, A., Gow, A. J., and Morey, R. M.: The in-situ dielectric constant of polar firn revisited, Cold Reg. Sci. Technol., 23, 245256, 1995.

Langer, M., Westermann, S., Heikenfeld, M., Dorn, W., and Boike, J.: Satellite-based modeling of permafrost temperatures in a tundra lowland landscape, Remote Sens. Environ., 135, 12-24, 2013.

Lehning, M. and Fierz, C.: Assessment of snow transport in avalanche terrain, Cold Reg. Sci. Technol., 51, 240-252, 2008.

Lewkowicz, A. G. and Ednie, M.: Probability mapping of mountain permafrost using the BTS method, Wolf Creek, Yukon Territory, Canada, Permafrost Periglac., 15, 67-80, 2004.

Li, L. and Pomeroy, J. W.: Estimates of Threshold Wind Speeds for Snow Transport Using Meteorological Data, J. Appl. Meteorol., 36, 205-213, 1997.

Liston, G. E.: Representing Subgrid Snow Cover Heterogeneities in Regional and Global Models, J. Climate, 17, 1381-1397, 2004.

Luce, C. H. and Tarboton, D. G.: The application of depletion curves for parameterization of subgrid variability of snow, Hydrol. Process., 18, 1409-1422, 2004.

Lussana, C., Uboldi, F., and Salvati, M. R.: A spatial consistency test for surface observations from mesoscale meteorological networks, Q. J. Roy. Meteorol. Soc., 136, 1075-1088, 2010.

Melvold, K. and Skaugen, T.: Multiscale spatial variability of lidarderived and modeled snow depth on Hardangervidda, Norway, Ann. Glaciol., 54, 273-281, 2013.

Nitta, T., Yoshimura, K., Takata, K., O'ishi, R., Sueyoshi, T., Kanae, S., Oki, T., Abe-Ouchi, A., and Liston, G. E.: Representing Variability in Subgrid Snow Cover and Snow Depth in a Global Land Model: Offline Validation, J. Climate, 27, 3318-3330, 2014.

Ødegaard, R. S., Isaksen, K., Eiken, T., and Sollid, J. L.: MAGST in Mountain Permafrost, Dovrefjell, Southern Nroway, 2001-2006, Ninth International Conference on Permafrost (NICOP) 2008, 29 June-3 July 2008, Fairbanks, Alaska, 2008.

Pomeroy, J., Essery, R., and Toth, B.: Implications of spatial distributions of snow mass and melt rate for snow-cover depletion: observations in a subarctic mountain catchment, Ann. Glaciol., 38, 195-201, 2004.

Reistad, M., Breivik, Ø., Haakenstad, H., Aarnes, O. J., Furevik, B. R., and Bidlot, J.-R.: A high-resolution hindcast of wind and waves for the North Sea, the Norwegian Sea, and the Barents Sea, J. Geophys. Res.-Oceans, 116, C05019, doi:10.1029/2010JC006402, 2011.

Saloranta, T. M.: Simulating snow maps for Norway: description and statistical evaluation of the seNorge snow model, The Cryosphere, 6, 1323-1337, doi:10.5194/tc-6-1323-2012, 2012.

Seppälä, M.: Synthesis of studies of palsa formation underlining the importance of local environmental and physical characteristics, Quaternary Res., 75, 366-370, 2011.

Skaugen, T.: Modelling the spatial variability of snow water equivalent at the catchment scale, Hydrol. Earth Syst. Sci., 11, 15431550, doi:10.5194/hess-11-1543-2007, 2007.

Skaugen, T., Alfnes, E., Langsholt, E. G., and Udnæs, H.-C.: Timevariant snow distribution for use in hydrological models, Ann. Glaciol., 38, 180-186, 2004.

Stephens, M. A.: EDF Statistics for Goodness of Fit and Some Comparisons, J. Am. Stat. Assoc., 69, 730-737, 1974.

Westermann, S., Schuler, T. V., Gisnås, K., and Etzelmüller, B.: Transient thermal modeling of permafrost conditions in South- 
ern Norway, The Cryosphere, 7, 719-739, doi:10.5194/tc-7-7192013, 2013.

Westermann, S., Østby, T., Gisnås, K., Schuler, T. V., and Etzelmüller, B.: A ground temperature map of the North Atlantic permafrost region based on remote sensing and reanalysis data, The Cryosphere, 9, 1303-1319, doi:10.5194/tc-9-13032015, 2015.

Winstral, A. and Marks, D.: Long-term snow distribution observations in a mountain catchment: Assessing variability, time stability, and the representativeness of an index site, Water Resour. Res., 50, 293-305, 2014.
Winstral, A., Elder, K., and Davis, R. E.: Spatial snow modeling of wind-redistributed snow using terrain-based parameters, J. Hydrometeorol., 3, 524-538, 2002.

Zhang, T., Barry, R. G., and Haeberli, W.: Numerical simulations of the influence of the seasonal snow cover on the occurrence of permafrost at high latitudes, Norsk Geogr. Tidsskr., 55, 261-266, 2001. 